\title{
Conversion to open surgery in the era of laparoscopic cholecystectomy: Rates and reasons
}

\section{Laparaskopik kolesistektomi çağında açık cerrahiye dönüş: Nedenler ve oranlar}

\author{
Ali Kağan Gökakın*, Mustafa Atabey, Boran Cihat Karakuş, Cengiz Aydın
}

Department of General Surgery (Assist. Prof. A. K. Gökakın, MD, M. Atabey, MD, B. C. Karakuş, MD, Prof. C. Aydın, MD), Cumhuriyet University School of Medicine, TR-58140 Sivas

\begin{abstract}
Aim. In the era of minimally invasive surgery; laparoscopic cholecystectomy has become the first choice for gallstone disease both for urgent and elective surgery .However, a number of cases still necessitate conversion to open procedures. Identifying the reasons and rates involved in conversion at the early period can help the surgeons in deciding when to exclude the choice of e laporoscopic procedure. The goal of this study is to evaluate the rates and causes of conversion to open cholecystectomy in elective cases. Methods. The study included all of the patients who had undergone elective surgery in our clinic due to gallstone disease from January, 1999 to December, 2010. Detection of malignancy and/or polyps, and existence of acute cholecystitis were accepted as criterion for exclusion. The existence of previous abdominal surgery, demographic parameters, and the causes and rates of conversion to open cholecystectomy were noted and analyzed. Results. Of the 823 patients for whom laparoscopic cholecystectomy was applied, 782 were included in this study. The rate of conversion was $6.1 \%(n=48)$ in total. Twenty of these 48 converted patients were male and 28 of them were female with a mean age of 49,27 years (range: 24-89). In male and female patients, the conversion rates were $9,8 \%$ and $4,8 \%$, respectively. Adhesions due to inflammation or prior abdominal surgery were found to be the most common reasons for conversion. Conclusion. There is no question that laparoscopic cholecystectomy is the gold standard when all other treatment modalities are considered. Laparoscopic cholecystectomy can be safely applied by experienced hands to all patients with a low conversion rate. Conversion should not be seen as a complication.
\end{abstract}

Keywords: Laparoscopic cholecystectomy, gallstone , laparatomy, cholecystectomy

\section{Özet}

Amaç. Minimal invaziv cerrahi çağında laparaskopik kolesistektomi, safra kesesi taşı hastalığında hem acil hem de elektif şartlarda ilk seçenek haline gelmiştir. Ancak, halen bazı hastalarda laparatomiye dönülmek zorunda kalınmaktadır. $\mathrm{Bu}$ tip vakaların önceden tespit edilerek laparaskopi tercihinden vazgeçilmesi için nedenlerinin ve oranlarının ortaya konması cerrahlara yardımcı olabilir. Bu çalışmanın amacı, elektif vakalarda laparaskopik yöntemden açık cerrahiye dönüş neden ve oranlarını ortaya koymaktır. Yöntem. Ocak 1999 ile Aralık 2010 arasında kliniğimizde safra taşı hastalığı nedeni ile elektif kolesistektomi yapılan tüm hastalar çalışmaya dahil edildi. Malignite ve/veya polip tespiti ve akut kolesistit varlığ çalışmada hariç tutma kriteri olarak kabul edildi.Önceki abdominal cerrahi varlığı, demografik özellikler, açığa dönüş neden ve oranları kaydedilerek analiz edildi. Bulgular. Çalışma periyodunu kapsayan dönemde laparaskopik kolesistektomi yapılan toplam 823 hastanın 782 'si çalışmaya dahil edildi. Toplam açığa dönüş oranı \% 6,1 (n=48) idi. Bu 48 hastanın 20'si erkek, 28'i kadın, ortalama yaşları 49,27 (aralık 24-89) idi. Erkek ve kadın hastalar için açığa dönüş oranları sırası ile \%9,8 ve \%4,8 idi. Daha önceki cerrahilere ve enflamasyona bağlı yapışıklık açık cerrahiye dönmenin en sı nedeni olarak tespit edildi. Sonuç. Tüm tedavi yaklaşımları göz önüne alındığında laparaskopik kolesistektominin safra taşı hastalığında altın standart olması konusunda herhangi bir soru işareti yoktur. Laparaskopik kolesistektomitecrübeli cerrahlar tarafindan tüm hastalarda düşük dönüşüm oranları ile güvenle uygulanabilir. Ancak açığa dönüş bir komplikasyon olarak görülmemelidir.

Anahtar sözcükler: Laparaskopik kolesistektomi, safra kesesi taşı, laparatomi, kolesistektomi 


\section{*Corresponding author:}

Dr. Mustafa Atabey, Genel Cerrahi Anabilim Dalı, Cumhuriyet Üniversitesi Tıp Fakültesi, TR58140 Sivas. E-posta: atabey21@gmail.com

\section{Introduction}

Gallstone disease is one of the most common health problems that surgeons face in daily practice. The great majority of patients are free of complaint, and cholelithiasis is usually detected with ultrasonography being performed for unrelated reasons. Compared to open surgery; LC has become the standard of care for the treatment of gallstone disease in the last two decades due to several important advantages including reduction in postoperative disability and pain, earlier oral intake, shorter hospital stay, earlier return to normal activity, and better cosmetic results [1-6]. On the other hand; the procedure can not be continued laparoscopically in all cases, and conversion to laparotomy may become inevitable. Conversion rates for gallstone disease have been the subject of various publications and reported with an average of 5\% (range: 2-20\%) [7-10]. An inability to delineate the anatomy, encountering unexpected operative findings, and iatrogenic injuries are reported in these publications as the most common causes (based on culture and geography, in addition to an understanding of conversion within the center) for conversion to an open procedure [11].

Herein we aimed to identif the rates and reasons involved in conversion to open procedure in elective surgery for gallstone disease over the course of ten years' at our institution.

\section{Materials and methods}

The study included all of the patients who were undergone elective laparoscopic cholecystectomies at our center due to gallstone disease from January, 1999 to December, 2010. Detection of malignancy and/or polyps and the existence of acute cholecystitis were accepted as the criterion for exclusion. Patient history of previous abdominal surgery, demographic parameters, indications for cholecystectomy, and the reasons and rates involved in conversion to open cholecystectomy were all analyzed. SPSS (Statistical Packages for Social Sciences) 11.5 software was used for statistical analysis. The chisquared test was used for comparisons of categorical variables. A value of $p<0.05$ was accepted as statistically significant.

\section{Results}

Of 823 patients for whom laparoscopic cholecystectomy was applied, 782 were included in the study. Detection of malignancy $(n=4)$ and/or polyps $(n=15)$ and the existence of acute cholecystitis $(n=22)$ were accepted as criterion for exclusion. Hepatobiliary ultrasonography, biochemical analysis including liver enzymes, and all necessary preoperative routine tests were applied in each case before the surgery. All operations were made by expert stuff surgeons or fellows under supervision, using the standard fourport, two-hand technique [12]. The demographic parameters and concomitant diseases of the patients are exhibited in Table 1. Of 782 patients with gallstone disease, 48 patients (6. $1 \%$ ) were converted to laparotomy due to a variety of reasons. Conversion rate was slightly decreased in time but this was not significant (Figure 1). The mean age was 49. 27 years (range: 24-89) in converted group while the mean age was 46. 36 years (range: $19-89)$ in the LC group. In the converted group there were 28 (58.3\%) females and 20 (41. 7\%) males whereas there were 551 (75. 1\%) females and $183(24.9 \%)$ males in the LC group. In male and female patients, the conversion rate was $9.8 \%$ and 4.8 , respectively $(\mathrm{p}=0.001)$. Concomitant diseases were detected more frequently in the converted group but statistical significance was not found. 
Table1. Demographic parameters of the patients

\begin{tabular}{llll}
\hline DATA & $\begin{array}{l}\text { Converted }(\mathbf{n}=\mathbf{4 8}) \\
\mathbf{( 6 . 1 \% )}\end{array}$ & $\begin{array}{l}\text { Nonconverted }(\mathbf{n = 7 3 4}) \\
\mathbf{( 9 3 . 9 \% )}\end{array}$ & P value \\
\hline Age $($ mean \pm SD) & $49.27 \pm 15.82$ & $46.25 \pm 14.35$ & Not Significant \\
Gender(male/female) n (\%) & $20(41.7) / 28(58.3)$ & $183(24.9) / 551(75.1)$ & $\leq 0.01$ \\
Comorbidity, $\mathrm{n}(\%)$ & $13(27)$ & $171(23)$ & Not Significant \\
\hline SD: Standard
\end{tabular}

SD: Standard deviation, Values in parentheses are percentages.

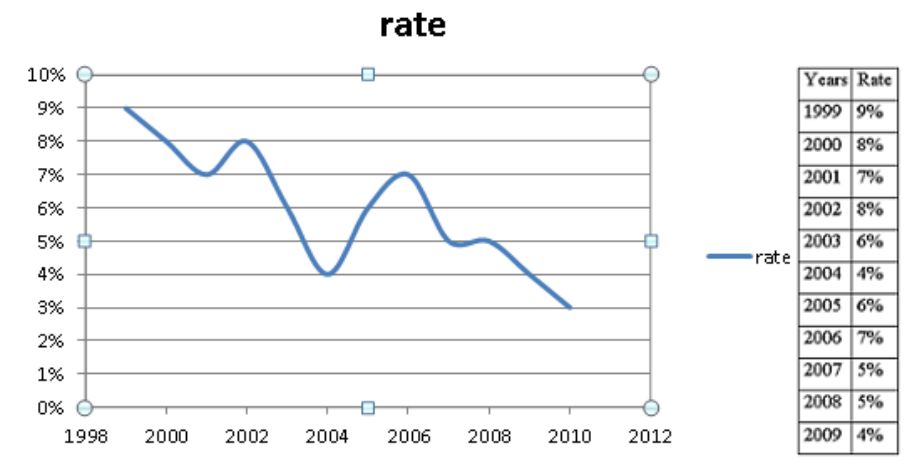

Figure 1. Conversion rate during the study period, $\mathbf{p} \geq \mathbf{0 . 0 0 5}$.

Adhesions ( $n=31)$ due to inflammation or prior abdomial surgery were found to be the most common reasons for conversion. Prior abdominal surgery was seen in 20 of these 31 patients while the rest of the adhesions were due to inlammation because of previous acute cholecystic attacs. Conversion to laparotomy because of intraoperative bleeding occurred in 7 patients $(0.08 \%$ ); and majority of these ( 4 of 7 ) were due to accidental damage to the cystic artery and the rest was because of hemorrhage in the liver bed. Hemorrhages due to cystic artery injury were controlled by simple ligation and the rest responded to electrocaoutery. No major vessel injury was detected. Anatomic variation that was difficult to resolve was the reason for conversion in another $7(0.08 \%)$ patients, but the distribution of these variations was not recorded. Only one duodenal injury was noted in the study and during the laparotomy it was observed that it did not involve the whole wall. Injury of the choleduct was found in two cases and both of them underwent hepaticojejunostomy. No trocar injury to the other luminated organs detected (Table 2).

Table2. Causes of conversion

\begin{tabular}{lll}
\hline Reason & Number & Percentage \\
\hline Adhesion (Prior Surgery/ Inflamation) & $31(20 / 11)$ & $64.6(41 / 23)$ \\
Bleeding Sistic Artery/Liver Bed) & $7(4 / 3)$ & $14.6(8.3 / 6.2)$ \\
Variation In Anatomy & 7 & 14.6 \\
Injury (Choleduct/ Duedonum) & $3(2 / 1)$ & $6.3(4.1 / 2.0)$ \\
\hline Total & 48 & 100 \\
\hline
\end{tabular}

\section{Discussion}

Laparoscopic cholecystectomy has become the first treatment option for symptomatic cholelithiasis in the last two decades due to the well-known advantages. Moreover, with gained experience, laparoscopic cholecystectomy has become safer and more costefficient in an ambulatory setting. Currently, surgery assistants are learning laparoscopic cholecystectomy before open cholecystectomy. Conversion to laparotomy causes unfavorable consequences in patients due to higher rates of postoperative complications and prolonged hospital stays [13]. However, in certain patients, conversion to an open procedure is inevitable. This rate of conversion is reported in different publications in a range of $2 \%$ to $15 \%[9,14]$. In our study; the conversion rate was detected as $6.1 \%$, 
which can be accepted compatible with the rates reported in the literature. The requirement for conversion should be seen as a salvage measure rather than a complication in some cases. Furthermore, despite better training for surgeons and better laparoscopic instruments, the conversion rate appears to have remained relatively stable over time. Male gender has been reported as a risk factor for conversion, attributable to a greater incidence of anatomical difficulties and delay in presentation [7, 15]. Similarly, age has been noted in the literature as a preoperative risk factor for conversion $[14,15]$. In our study, male gender was found to be associated with conversion. On the other hand, no difference was detected in terms of age. This difference can be explained by the exclusion of acute cholecystitis in our study. It appears that severe adhesions due to prior abdominal surgery or inflammation because of acute cholecystitis present two of the most frequent situations that require conversion according to the literature $[9,15]$. Sanabria et al. [7] examined risk factors predicting conversion in an elective cholecystectomy, as we did, and they found that in 628 elective laparoscopic cholecystectomies in elderly patients (65 years or older), males, and patients with multiple attacks (more than 10) of biliary colic, or with a documented history of acute cholecystitis, were more likely to require conversion. Genc et al. [11] investigated what factors necessitate the conversion to open cholecystectomy in their study of 5,164 patients and they also concluded that adhesios were the most common reason for conversion. In this study, we saw similar findings that $31(64.6 \%)$ of all conversions were due to adhesions. We also excluded patients with acute cholecystitis, but these adhesions could be due to previous attacks of acute cholecystitis.

Nevertheless, we determined that bile duct injuries, bleeding and anatomic variations were important factors that lead to conversion, but there was no significant difference related to adhesions. In the era of minimally invasive surgery; laparoscopic cholecystectomy is the first choice in the treatment of gallstone disease, but, as a conclusion, we suggest that, surgeons should not hesitate to convert to open cholecystectomy when laparoscopic difficulties begin to compromise patient safety, especially in males with a history of repeated acute cholecystitis.

\section{References}

1. A prospective analysis of 1518 laparoscopic cholecystectomies. The Southern Surgeons Club. N Engl J Med 1991; 324: 1073-8.

2. Cuschieri A, Dubois F, Mouiel J, Mouret P, Becker H, Buess G, Trede M, Troidl H. The European experience with laparoscopic cholecystectomy. Am J Surg 1991; 161: 385-7.

3. Buanes T, Mjaland O. Complications in laparoscopic and open cholecystectomy: a prospective comparative trial. Surg Laparosc Endosc 1996; 6: 266-72.

4. Trondsen E, Reiertsen O, Andersen OK, Kjaersgaard P. Laparoscopic and open cholecystectomy. A prospective, randomized study. Eur J Surg 1993; 159: 217 21.

5. Bittner R. Laparoscopic surgery--15 years after clinical introduction. World J Surg 2006; 30: 1190-203.

6. Ros A, Gustafsson L, Krook H, Nordgren CE, Thorell A, Wallin G, Nilsson E. Laparoscopic cholecystectomy versus mini-laparotomy cholecystectomy: a prospective, randomized, single-blind study.Ann Surg 2001; 234: 741-9.

7. Sanabria JR, Gallinger S, Croxford R, Strasberg SM. Risk factors in elective laparoscopic cholecystectomy for conversion to open cholecystectomy. J Am Coll Surg 1994; 179: 696.

8. Schrenk P, Woisetschläger R, Wayand WU. Laparoscopic cholecystectomy. Cause of conversions in 1,300 patients and analysis of risk factors. Surg Endosc 1995; 9: 25.

9. Alponat A, Kum CK, Koh BC, Rajnakova A, Goh PM. Predictive factors for conversion of laparoscopic cholecystectomy. World J Surg 1997; 21: 629. 
10. Kama NA, Kologlu M, Doganay M, Reis E, Atli M, Dolapci M. A risk score for conversion from laparoscopic to open cholecystectomy. Am J Surg 2001; 181: 520-5.

11. Genc V, Sulaimanov M, Cipe G, Basceken SI, Erverdi N, Gurel M, Aras N, Hazinedaroglu SM. What necessitates the conversion to open cholecystectomy? A retrospective analysis of 5164 consecutive laparoscopic operations. Clinics (Sao Paulo) 2011; 66: 417-20.

12. Nathanson LK, Shimi S, Cuschieri A. Laparoscopic cholecystectomy: the Dundee technique. Br J Surg 1991; 78: 155

13. Simopoulos C, Botaitis S, Polychronidis A, Tripsianis G, Karayiannakis AJ. Risk factors for conversion of laparoscopic cholecystectomy to open cholecystectomy. Surg Endosc 2005; 19: 905-9.

14. Wiebke EA, Pruitt AL, Howard TJ, Jacobson LE, Broadie TA, Goulet RJ Jr, Canal DF. Conversion of laparoscopic to open cholecystectomy. An analysis of risk factors. Surg Endosc 1996; 10: 742-5.

15. Fried GM, Barkun JS, Sigman HH, Joseph L, Clas D, Garzon J, Hinchey EJ, Meakins JL. Factors determining conversion to laparotomy in patients undergoing laparoscopic cholecystectomy. Am J Surg. 1994; 167: 35-9; discussion 39-41. 